\title{
Occurrence and characterization of entomogenic galls in an area of Cerrado sensu stricto and Gallery forest of the state of Bahia, Brazil
}

\author{
APARECIDA RAVENE F. DA SILVA ${ }^{1}$, RAVENA M. NOGUEIRA ${ }^{2}$, ELAINE C. COSTA ${ }^{1,3}$, \\ SHEILA P. CARVALHO-FERNANDES ${ }^{4}$ and JULIANA SANTOS-SILVA ${ }^{2}$ \\ ${ }^{1}$ Departamento de Ciências Humanas, Campus VI, Universidade do Estado da Bahia, \\ Avenida Contorno, s/n, Centro, 46400-000 Caetité, BA, Brazil \\ ${ }^{2}$ Programa de Pós-Graduação em Biodiversidade Vegetal, Departamento de Educação, Universidade \\ do Estado da Bahia, Rua da Gangorra, 503, 48608-240 Paulo Afonso, BA, Brazil \\ ${ }^{3}$ Programa de Pós-Graduação em Biologia Vegetal, Departamento de Botânica, Universidade Federal de \\ Minas Gerais, Avenida Antônio Carlos, 6627, Pampulha, 31270-901 Belo Horizonte, MG, Brazil \\ ${ }^{4}$ Departamento de Entomologia, Museu Nacional, Universidade Federal do Rio de Janeiro, \\ Quinta da Boa Vista, s/n, São Cristóvão, 20940-040 Rio de Janeiro, RJ, Brazil
}

Manuscript received on July 16, 2017; accepted for publication on March 7, 2018

\begin{abstract}
We surveyed insect galls in an area of Cerrado sensu stricto and Gallery forest in the municipality of Caetité (BA) to contribute to current knowledge of the local flora and its associated gall-inducing insects. Monthly collections were made between February/2015 and January/2016, totaling 12 field campaigns (involving two or three people and lasting four hours) that followed an established path through the countryside. A total of 63 gall morphotypes were identified on 47 host plant species belonging to 22 families; 17 morphotypes were found in the Gallery forest and 46 in Cerrado vegetation. The plant families showing the greatest gall richness were Leguminosae $(n=15)$, Myrtaceae $(n=9)$, and Asteraceae $(n=7)$. The species with the greatest number of galls was Mimosa gemmulata Barneby (Leguminosae) ( $\mathrm{n}=3)$. Most galls were observed on leaves $(66 \%)$ and stems $(24 \%)$; they were mostly green $(49.3 \%)$ or brown $(26 \%)$, with globoid shapes (39.7\%) or marginal roll (17.4\%), and were unilocular (87\%), glabrous (62\%) and isolated (89\%). Cecidomyiidae (Diptera) were the principal gall-inducing insects. The associated fauna was principally composed of Hymenoptera. Eight plant taxa were recorded for the first time as hosts of galling fauna.
\end{abstract}

Key words: Cecidomyiidae, plant-insect interactions, Leguminosae, semiarid.

\section{INTRODUCTION}

Many insect species associate with plants to increase their chances of survival. Those interactions between insect and their host plants can be mutualistic, benefiting both of the associated

Correspondence to: Juliana Santos-Silva

E-mail: jussilva@uneb.br individuals, or they may benefit only one of the organisms involved - as is the case of parasitism (Price 1991). Insect parasites generally do not kill their host plant, although they may harm them by feeding on vital organs (Begon et al. 2007).

Gall-inducing insects are excellent examples of parasites that induce morphological and anatomical alterations in plant tissues or organs 
through processes of hyperplasia and hypertrophy (Mani 1964). These processes are stimulated by mechanical or chemical factors originated from the insects (Hori 1992), and can interfere with the flux of the photosynthates and nutrients produced by those plants (Schoonhoven et al. 2005).

Galls, also known as cecidia, provide protection for the immature stages of the inducing insects against abiotic environmental factors such as sunlight excess and water stress as well against natural enemies (Stone and Schönrogge 2003). Galls can occur on essentially all plant organs, from the extremities of their roots to their apical buds, and both on vegetative and reproductive parts - although they are more numerous and diversified on the aerial portions of the plants, especially on leaves (Mani 1964, Maia 2013).

Studies on galls have increased expressively in recent years in Brazil. Most of them regards inventories of gall diversity in different ecosystems (e.g., Araújo et al. 2012, Costa et al. 2014a, b, Nogueira et al. 2016), while others have investigated ecological aspects of gall-inducing insects or described new species (e.g., Maia and Souza 2007, Maia et al. 2010, Maia 2014), as well as the structural and ultrastructural natures of gall tissues (e.g., Arduin and Kraus 2001, Moura et al. 2009, Oliveira and Isaias 2010, Isaias et al. 2011, Suzuki et al. 2015). Additional studies have focused on the importance of galls as bioindicators (Moreira et al. 2007, Oliveira 2009).

Gall inventories have concentrated in the southeastern region of Brazil, with the Cerrado and Atlantic Forest biomes being the most intensively studied (e.g., Fernandes et al. 1996, GonçalvesAlvim and Fernandes 2001, Maia and Fernandes 2004, Fernandes et al. 2009). Few studies have focused on dryland Caatinga vegetation (Santos et al. 2011, Silva et al. 2011, Carvalho-Fernandes et al. 2012, Costa 2016), the Amazon Forest (Almada and Fernandes 2011, Maia 2011, Silva et al. 2011, Araújo et al. 2012, Julião et al. 2014), and Caatinga-
Cerrado ecotones (Costa et al. 2014a, b, Nogueira et al. 2016).

In spite of recent progress, the knowledge on the diversity and distribution of galls in Bahia State is still relatively limited. Most sampling efforts have been concentrated in the southwestern region of the state, with studies in the Gallery forests (Costa 2016), Cerrado (Costa 2016, Nogueira et al. 2016), Caatinga (Santos et al. 2011, CarvalhoFernandes et al. 2012, Costa 2016), and CaatingaCerrado transition zones (Costa et al. 2014a, b, Nogueira et al. 2016). Additionally, five new records of species of Cecidomyiidae were recently reported for that state (Maia 2014). In Caetité only three Cecidomyiidae species are known (Gagné and Jaschhof 2017), Styraxdiplosis caetitensis Tavares, 1915 and Dialeria styracis Tavares, 1918 associated with undetermined species of Styrax (Styracaceae), and Anadiplosis caetetensis Tavares, 1920 in an undetermined species of Mimosoideae (Leguminosae), now Mimosoid clade (LPWG 2017).

This situation is worrisome as the biodiversity of Bahia is increasingly threatened by deforestation for pasture formation, agriculture, civil construction, and the illegal extraction of wood products (Ministério do Meio Ambiente 2002). The conversion of natural environments into urban and agricultural areas leads to the loss and fragmentation of habitats and consequent biodiversity reductions and disruptions of plantinsect interactions (Tabarelli 1998). Previous studies have demonstrated that the richness of entomogenous galls in the interior of forest fragments responds negatively to anthropogenic disturbances, diminishing sharply as biodiversity losses and increasing plant mortality rates impoverish those fragments (Urso-Guimarães et al. 2003, Moreira et al. 2007).

Within that context, we undertook a survey of insect galls and their host plants in an area 
of Cerrado and Gallery forest vegetation in the municipality of Caetité, Bahia State, Brazil.

\section{MATERIALS AND METHODS}

Current study was undertaken along the Jacaraci

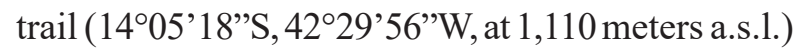
located along the urban border of the municipality of Caetité (BA). The trail is approximately 3 kilometers long and passes through areas of Cerrado sensu stricto vegetation growing on sandy soils with exposed rock outcrops, as well as a Gallery forest along the Riacho Alegre Creek.

Collections were undertaken on a monthly basis between February/2015 and January/2016, totalling 12 field campaigns along the entire extension of the trail. All plant architectures (herbs, shrubs, trees, and vines) visible up to $3 \mathrm{~m}$ above the ground were searched for galls involving two or three people and lasting approximately 4 hours each. When encountered, the galls were photographed and classified into morphotypes following Isaias et al. (2013).

Plant voucher specimens were collected in the field and subsequently prepared for herbarium storage at the Laboratório de Botânica of the Departamento de Ciências Humanas, Campus VI at the Universidade do Estado da Bahia. The plants were identified using analytical keys from the specialized literature, as well as by comparisons with herbarium specimens previously identified by specialists and held in the herbaria of the Universidade do Estado da Bahia (HUNEB/Caetité Collection) and Universidade Estadual de Feira de Santana (HUEFS). One voucher of each species was deposited in the HUNEB/Caetite Collection herbarium. The taxon list is organized alphabetically according to family, genus, and species, following the APG IV classification system (2016).

Some of the collected galls were held in plastic pots with moistened paper towels in the Laboratório de Botânica of the Universidade do Estado da Bahia
- DCH/Campus VI to allow eclosion of the inducing insects. The remaining galls were examined under a stereomicroscope and any immature forms of the insects were removed for identification and the numbers of chambers in the galls were counted. Any immature or adult insects were stored in $70 \%$ ethanol. The identifications of immature forms (without corresponding adult insects) were made by comparisons with insect morphotypes and host plants previously identified in Cerrado vegetation and in Gallery forests. All the examined material was deposited in the Entomological Collection of the Museu Nacional (MNRJ /UFRJ).

\section{RESULTS}

We recorded 63 gall morphotypes on 47 host plant species belonging to 22 families in the vegetation along the Jacaraci trail (Table I). Of the total number of galls (63), 17 were observed in the Gallery forest (on 14 plant species of 9 families) and 46 in Cerrado vegetation (on 33 plant species of 16 families). The plant families with the greatest gall richness were Leguminosae (Fabaceae) $(n=15)$, Myrtaceae $(n=9)$, and Asteraceae $(n=7)$. The Leguminosae had the largest number of host species (nine), followed by Myrtaceae and Malpighiaceae (seven and five species, respectively). Bauhinia L. (LeguminosaeCercidoideae), Mimosa L. (LeguminosaeCaesalpinioideae), Guarea F.Allam. ex L. (Meliaceae), and Eugenia L. (Myrtaceae) were the genera that hosted the greatest number of galls $(6$, 3 , 3, and 3, respectively). The species showing the greatest gall richness was Mimosa gemmulata Barneby, with three associated morphotypes.

Most of the gall morphotypes were encountered on a single plant organ (81\%) of a single host plant; five plant species had galls on both their leaves and stems (11\%) (Bauhinia sp., Bauhinia acaruana Moric., Celtis iguanaea (Jacq.) Sarg., Mimosa gemmulata, and Moraceae Indet); two species have galls on their buds and stems $(6 \%)$ 
APARECIDA RAVENE F. DA SILVA et al.

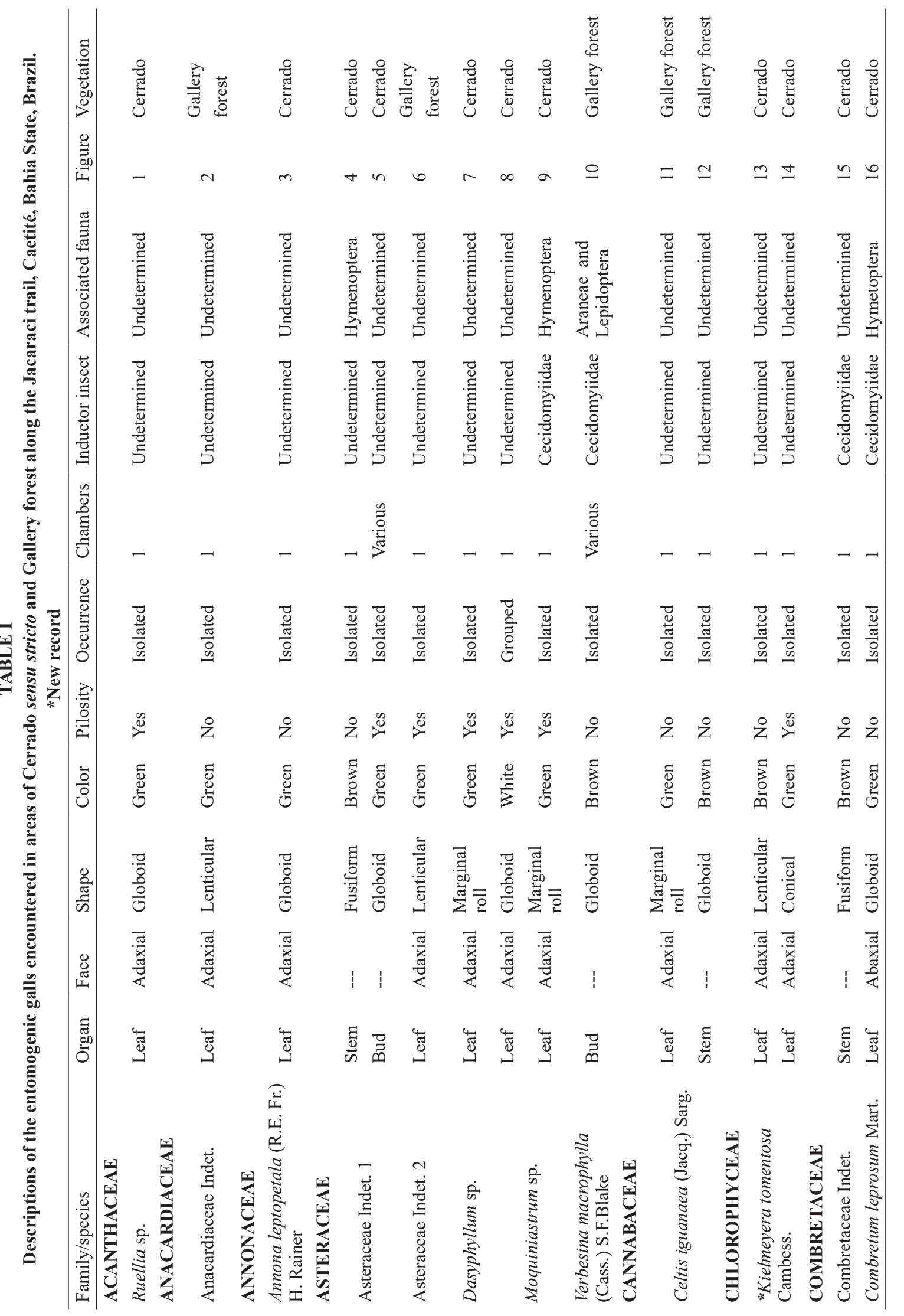




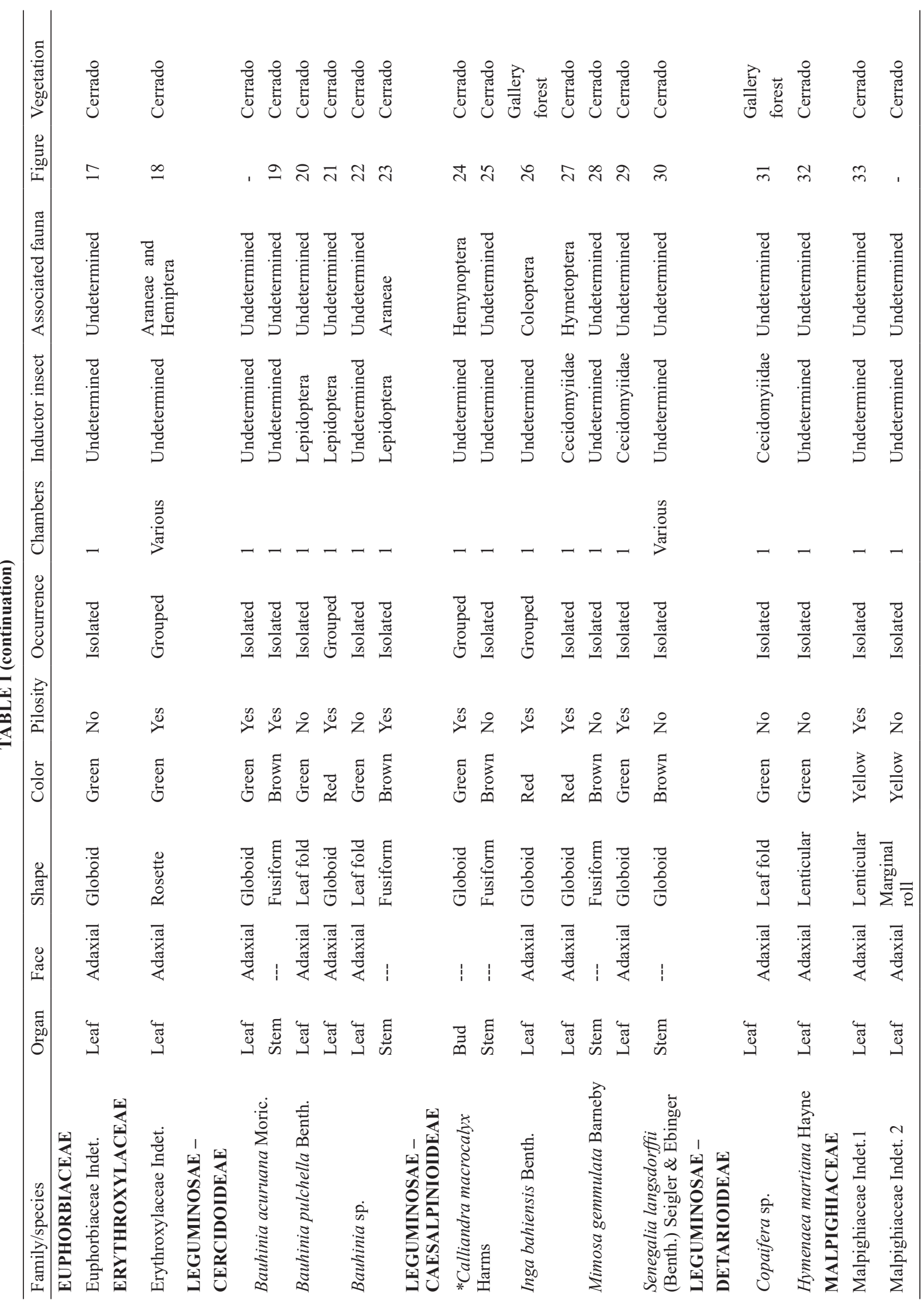




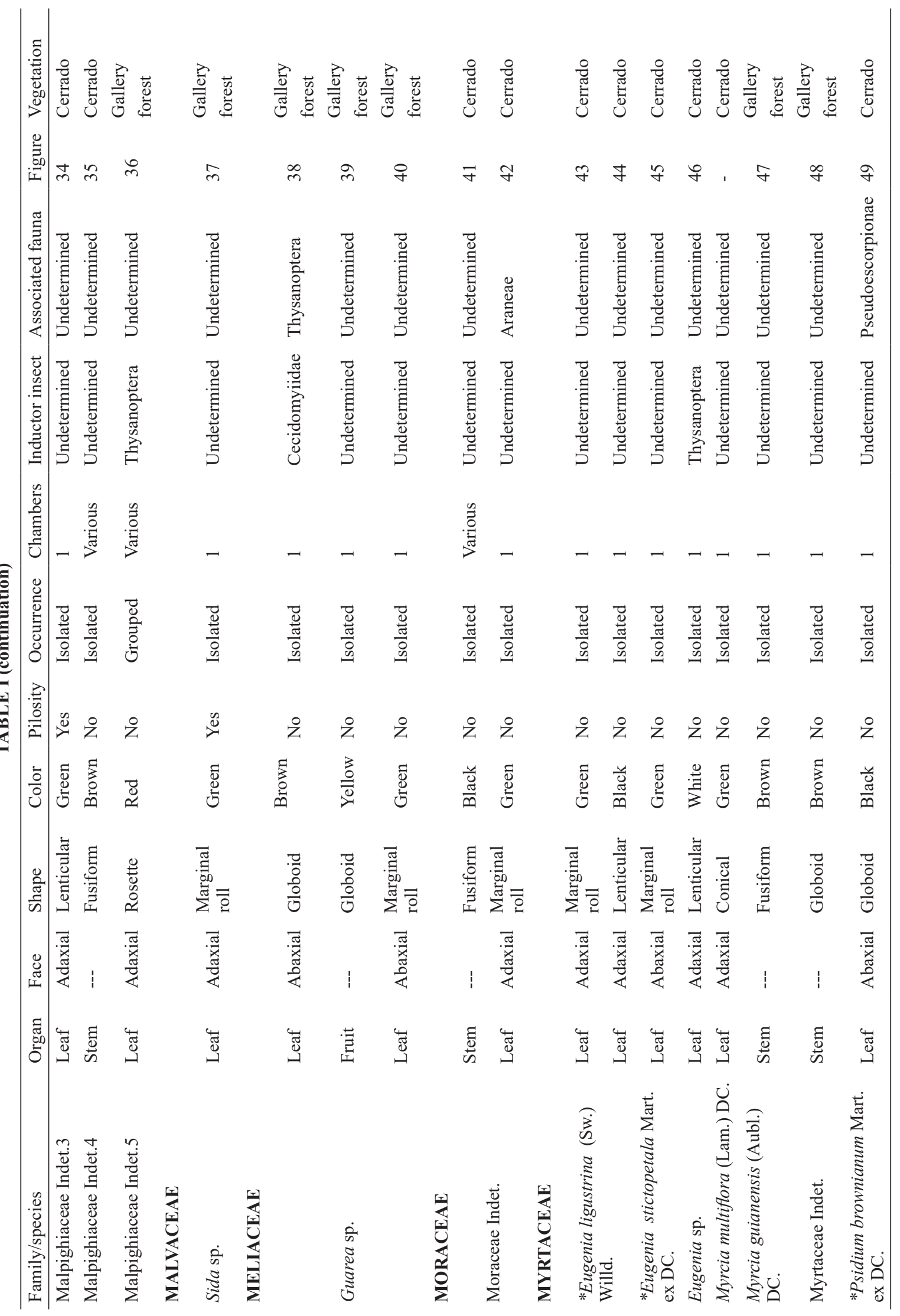


GALLS OF CERRADO AND GALLERY FOREST OF BAHIA

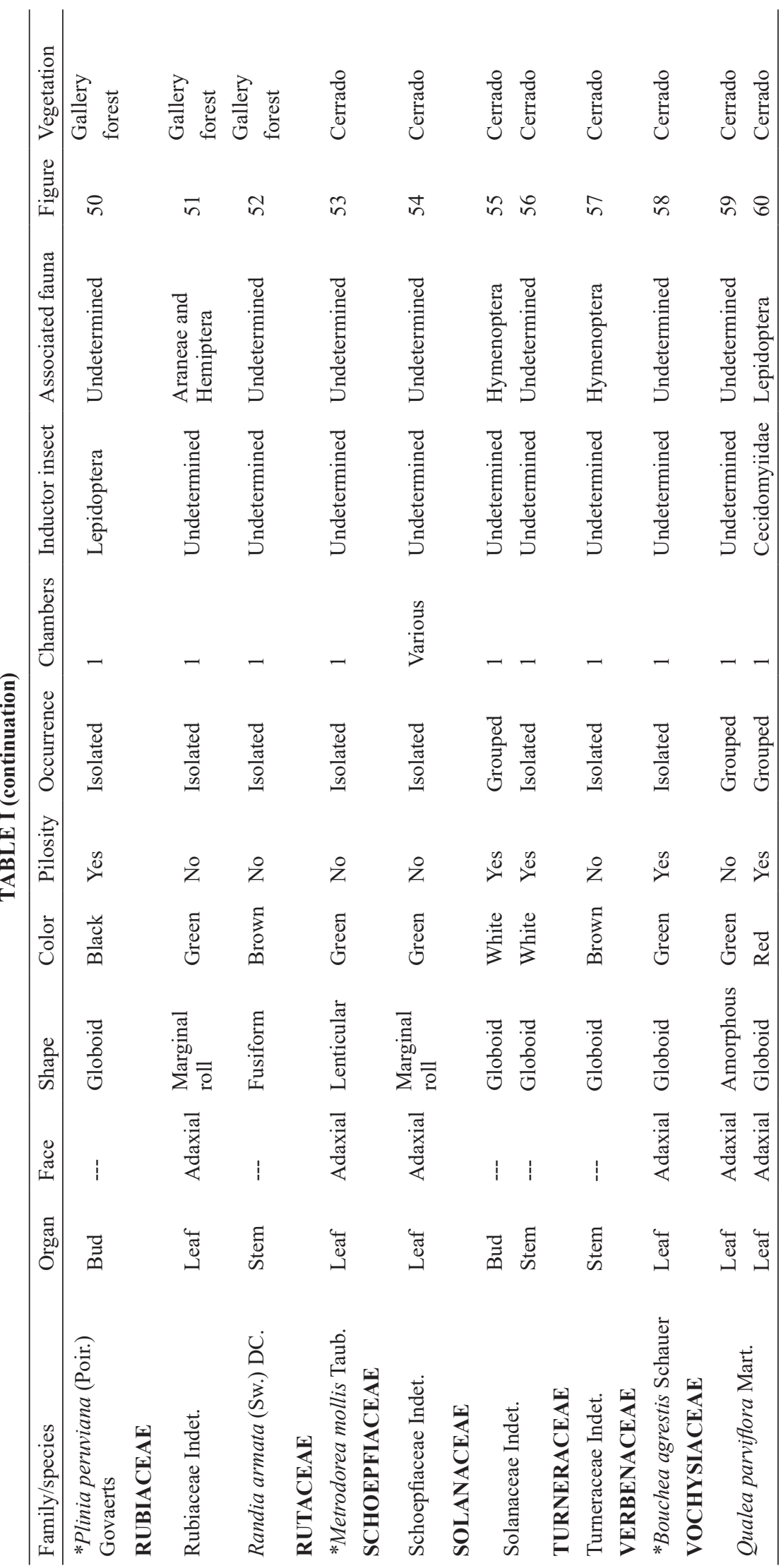


(Asteraceae Indet. and Solanaceae Indet.) or on a leaf and a fruit (2\%) (Guarea sp.). The predominant morphotypes were globoid (39.7\%), marginal roll $(17.4 \%)$, fusiform $(15.8 \%)$, unilocular $(87 \%)$, glabrous (62\%), and occurring isolated (89\%). The galls varied in color: green, brown, black, white, yellow, and red. Green was the most prevalent color $(49.3 \%)$, predominating on leaves $(66 \%)$, but green galls were also observed on buds and stems. Brown was the second predominant color $(26 \%)$, being predominately observed on plant stems $(24 \%)$.

This was the first inventory of galls and their host plants in an area of Gallery forest in Caetité. As such, all records are new for the region. We also recorded the new occurrence of galls on seven Cerrado plant species: Bouchea agrestis Schauer (Fig. 58), Calliandra macrocalyx Harms (Figs. 24-25), Eugenia ligustrina (Sw.) Willd. (Figs. 43-44), Eugenia stictopetala Mart. ex DC. (Fig. 45), Metrodorea mollis Taub. (Fig. 53), Psidium brownianum Mart. ex DC. (Fig. 49), Kielmeyera tomentosa Cambess. (Fig. 13), and on a new plant species in the Gallery forest: Plinia peruviana (Poir.) Govaerts (Fig. 50).

The gall-inducing insects identified belonged to the orders Diptera $(n=9)$, Lepidoptera $(n=4)$, and Thysanoptera $(n=2)$. The associated fauna included Hymenoptera $(n=8)$, Aranae $(n=5)$, Hemiptera $(n=2)$, Lepidoptera $(n=2)$, Thysanoptera $(n=2)$, Coleoptera $(\mathrm{n}=1)$, and Pseudoescorpionae $(\mathrm{n}=1)$.

\section{DISCUSSION}

Leguminosae, Myrtaceae, and Asteraceae served as hosts for the largest variety of gall morphotypes along the Jacaraci trail; they are also among the principal families bearing galls in different Brazilian ecosystems, especially the Cerrado (GonçalvesAlvim and Fernandes 2001, Urso-Guimarães and Scareli-Santos 2006, Araújo et al. 2012) (Table II).

The Leguminosae hosted the greatest diversity of gall morphotypes in Cerrado areas (Gonçalves-
Alvim and Fernandes 2001, Araújo et al. 2011, Luz et al. 2012). This gall richness may reflect the high number of species of Leguminosae in that vegetation type (approximately 879), but also the high numbers of their species associated with gallinducing insects (Mendonça 2007). Asteraceae is the second largest family in terms of the number of species in that biome (Mendonça et al. 2008), with approximately 1,251 species belonging to 190 genera (Asteraceae in Lista de Espécie da Flora do Brasil 2020 em construção). These families are also representative with the greatest richness of galls in Gallery forest (Urso-Guimarães et al. 2003, Bergamini et al. 2017).

The plant genera with the greatest number of galls were: Bauhinia $(\mathrm{n}=6)$ (LeguminosaeCercidoideae), Mimosa ( $\mathrm{n}=3$ ) (LeguminosaeCaesalpinioideae), Guarea (Meliaceae) $(\mathrm{n}=3)$, and Eugenia (Myrtaceae) $(\mathrm{n}=3)$. The genus Bauhinia was reported to be a super-host in the states of Minas Gerais (Coelho et al. 2009), Pernambuco (Santos et al. 2011), and Bahia (Costa et al. 2014a, Nogueira et al. 2016) in Caatinga, Cerrado and CaatingaCerrado transition areas. The genus Mimosa was reported in the state of Bahia (Nogueira et al. 2016), Guarea in São Paulo (Maia et al. 2008) and Eugenia in Rio de Janeiro (Maia 2001, Maia and Oliveira 2010) in Cerrado and Restinga areas. Our results differed from other inventories undertaken in Gallery forest and Cerrado vegetation, which showed the genera Qualea Aubl. (Vochysiaceae), Protium Burm. f. (Burseraceae), Baccharis L. (Asteraceae), and Byrsonima Rich. ex Kunth (Malpighiaceae) as the plant species demonstrating the greatest number of galls (Table II) (UrsoGuimarães et al. 2003, Araújo et al. 2011, Santos et al. 2012, Carneiro et al. 2009, Coelho et al. 2013, Costa 2016, Bergamini et al. 2017).

Mimosa gemmulata had the largest number of galls. Studies undertaken by Costa (2016) in the Parque Estadual Serra dos Montes Altos, Bahia, showed that same species as a super-host, with five 

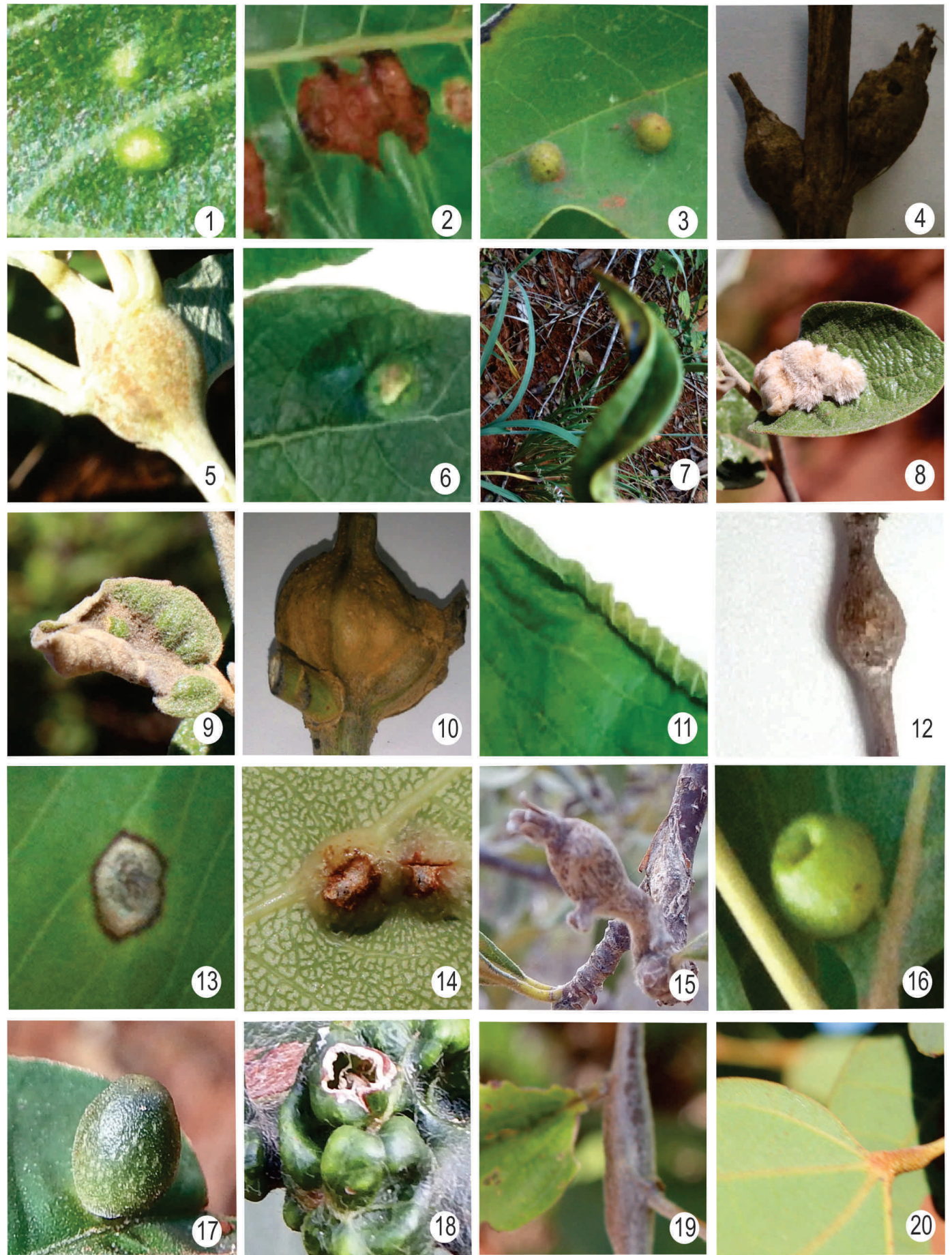

Figures 1-20 - Insect galls encountered along the Jacaraci trail in Caetité, Bahia State, Brazil and the associated morphotypes. 1, Ruellia sp., globoid. 2, Anacardiaceae Indet., lenticular. 3, Annona leptopetala (R.E. Fr.) H. Rainer, globoid. 4-5, Asteraceae Indet.1, 4, fusiform, 5, globoid. 6, Asteraceae Indet.2, lenticular. 7, Dasyphyllum sp., marginal roll. 8-9, Moquiniastrum sp., 8, globoid, 9, marginal roll. 10, Verbesina macrophylla (Cass.) S.F. Blake, globoid. 11-12, Celtis iguanaea (Jacq.) Sarg., 11, marginal roll, 12, globoid. 13-14, Kielmeyera tomentosa Cambess., 13, lenticular, 14, conical. 15, Combretaceae Indet., fusiform. 16, Combretum leprosum Mart., globoid. 17, Euphorbiaceae Indet., globoid. 18, Erythroxilaceae Indet., rosette. 19, Bauhinia acuruana Moric., fusiform. 20, Bauhinia pulchella Benth., leaf fold. 

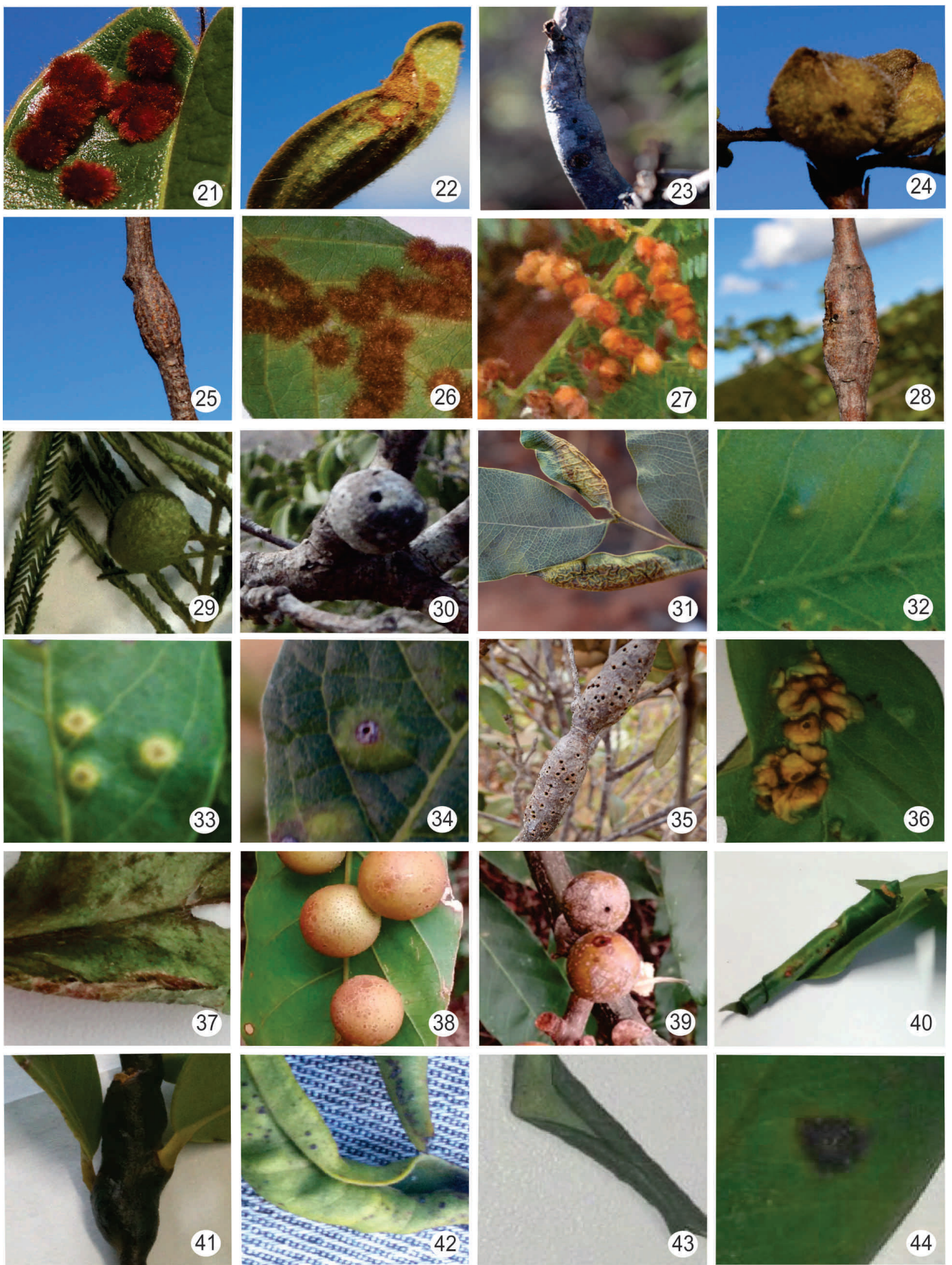

Figures 21-44 - Insect galls encountered along the Jacaraci trail in Caetité, Bahia State, Brazil and the associated morphotypes. 21-23, Bauhinia sp., 21, globoid, 22, leaf fold, 23, fusiform. 24-25, Calliandra macrocalyx Harms, 24, globoid, 25, fusiform. 26, Inga bahiensis Benth., globoid. 27-29, Mimosa gemmulata Barneby, 27, globoid, 28, fusiform, 29, globoid. 30, Senegalia langsdorffii (Benth.) Seigler \& Ebinger, globoid. 31, Copaifera sp., leaf fold. 32, Hymenaea martiana Hayne, lenticular. 33, Malpighiaceae Indet.1, lenticular. 34, Malpighiaceae Indet.3, lenticular. 35, Malpighiaceae Indet.4, fusiform. 36, Malpighiaceae Indet.5, rosette. 37, Sida sp., marginal roll. 38-40, Guarea sp., 38, globoid, 39, globoid, 40, marginal roll. 41-42, Moraceae Indet, 41, fusiform, 42, marginal roll. 43-44, Eugenia ligustrina (Sw.) Willd., 43, marginal roll, 44, lenticular. 

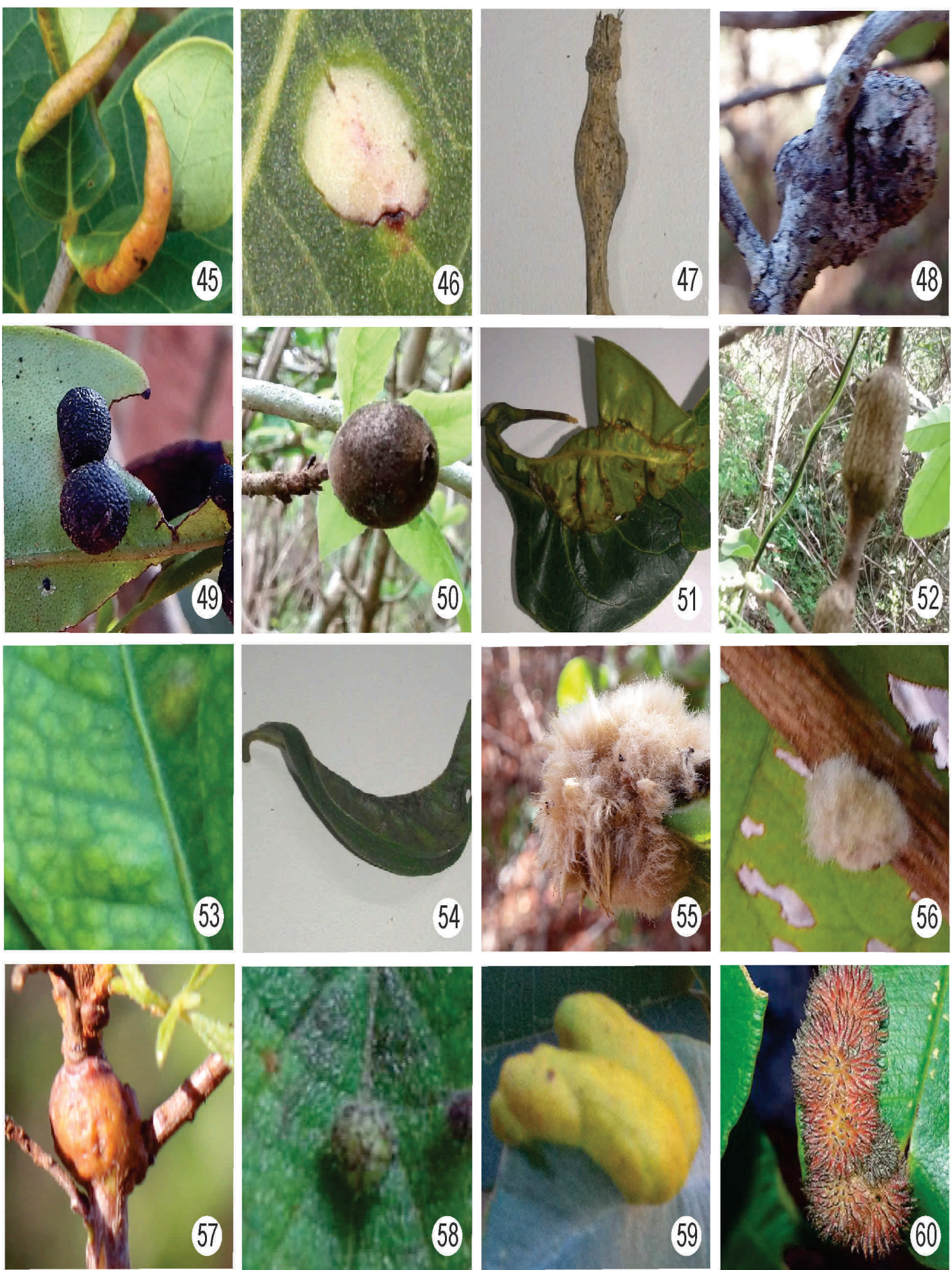

Figures 45-60 - Insect galls encountered along the Jacaraci trail in Caetité, Bahia State, Brazil and the associated morphotypes. 45, Eugenia stictopetala Mart. ex DC., marginal roll. 46, Eugenia sp., lenticular. 47, Myrcia guianensis (Aubl.) DC., fusiform. 48, Myrtaceae Indet, globoid. 49, Psidium brownianum Mart. ex DC., globoid. 50, Plinia peruviana (Poir.) Govaerts, globoid. 51, Rubiaceae Indet., marginal roll. 52, Randia armata (Sw.) DC., fusiform. 53, Metrodorea mollis Taub., lenticular. 54, Schoepfiaceae Indet., marginal roll. 55-56, Solanaceae Indet., 55, globoid, 56, globoid. 57, Turneraceae Indet., globoid. 58, Bouchea agrestis Schauer, globoid. 59-60, Qualea parviflora Mart., 59, amorphous, 60, globoid. 
TABLE II

Richness of gall morphotypes in host plants of Cerrado sensu stricto and Gallery forest in Brazil.

\begin{tabular}{|c|c|c|c|c|c|c|}
\hline Locality & Biomes & Richest families & Richest genera & Richest species & $\begin{array}{c}\text { Number of } \\
\text { morphotypes }\end{array}$ & $\begin{array}{c}\text { Mean of } \\
\text { morphotypes }\end{array}$ \\
\hline $\begin{array}{c}\text { Caetité, BA (the } \\
\text { present study) }\end{array}$ & $\begin{array}{l}\text { Gallery } \\
\text { forest } \\
\text { Cerrado }\end{array}$ & $\begin{array}{c}\text { Leguminosae (15) } \\
\text { Myrtaceae (9) } \\
\text { Asteraceae (7) }\end{array}$ & $\begin{array}{l}\text { Bauhinia L. } \\
\text { (6) Mimosa } \\
\text { L. (3) Guarea } \\
\text { F.Allam. ex } \\
\text { L. (3) } \\
\text { Eugenia L. (3) }\end{array}$ & $\begin{array}{c}\text { Mimosa gemmulata } \\
\text { Barneby (3) }\end{array}$ & 63 & 1.3 \\
\hline $\begin{array}{c}\text { Goiás, GO } \\
\text { (Bergamini et al. } \\
\text { 2017) }\end{array}$ & $\begin{array}{l}\text { Gallery } \\
\text { forest } \\
\text { Cerrado }\end{array}$ & $\begin{array}{c}\text { Leguminosae (18) } \\
\text { Asteraceae (17) } \\
\text { Sapindaceae (16) } \\
\text { Burseraceae e } \\
\text { Myrtaceae (14) } \\
\text { Siparunaceae (12) } \\
\text { Celastraceae e } \\
\text { Rubiaceae (10) }\end{array}$ & $\begin{array}{l}\text { Protium Burm. } \\
\text { f. (14) } \\
\text { Siparuna Aubl. } \\
\text { Sy (12) } \\
\text { Serjania Mill. } \\
\text { (12) } \\
\text { Bauhinia (10) }\end{array}$ & $\begin{array}{c}\text { Protium } \\
\text { heptaphyllum (Aubl.) } \\
\text { Marchand (14) } \\
\text { Siparuna guianensis } \\
\text { Aubl. (12) } \\
\text { Serjania sp. (12) }\end{array}$ & 186 & 3 \\
\hline $\begin{array}{l}\text { Serra de Caetité, } \\
\text { BA (Nogueira et } \\
\quad \text { al. 2016) }\end{array}$ & Cerrado & $\begin{array}{l}\text { Leguminosae (22) } \\
\text { Malpighiaceae (10) }\end{array}$ & $\begin{array}{l}\text { Copaifera } \\
\text { Desf. (10) } \\
\text { Bauhinia (6) } \\
\text { Mimosa (4) }\end{array}$ & $\begin{array}{c}\text { Copaifera } \\
\text { langsdorffii Desf. (9) } \\
\text { Bauhinia acuruana } \\
\text { Moric. (5) }\end{array}$ & 49 & 3.5 \\
\hline $\begin{array}{c}\text { Goiás, GO } \\
\text { (Araújo et al. } \\
\text { 2015) }\end{array}$ & Cerrado & $\begin{array}{l}\text { Leguminosae (58) } \\
\text { Malpighiaceae (29) } \\
\text { Myrtaceae (28) } \\
\text { Vochysiaceae (27) }\end{array}$ & $\begin{array}{c}\text { Byrsonima } \\
\text { Rich. ex Kunth } \\
\text { (22) } \\
\text { Qualea Aubl. } \\
\text { (21) Myrcia } \\
\text { DC. (17) }\end{array}$ & $\begin{array}{c}\text { Byrsonima } \\
\text { pachyphylla A. } \\
\text { Juss. (8) Protium } \\
\text { heptaphyllum (8) } \\
\text { Qualea parviflora } \\
\text { Mart. (8) } \\
\text { Styrax pohlii A. DC. } \\
\text { (8) }\end{array}$ & 365 & 2 \\
\hline $\begin{array}{l}\text { Goiânia, GO } \\
\text { (Araújo et al. } \\
\text { 2014) }\end{array}$ & Cerrado & $\begin{array}{c}\text { Myrtaceae (17) } \\
\text { Leguminosae (14) }\end{array}$ & $\begin{array}{c}\text { Myrcia (10) } \\
\text { Qualea (8) } \\
\text { Byrsonima } \\
\quad(6) \\
\text { Andira Lam. } \\
\quad \text { (4) }\end{array}$ & $\begin{array}{c}\text { Andira cujabensis } \\
\text { Benth. (4) } \\
\text { Myrcia guianensis } \\
\text { (Aubl.) DC. (4) } \\
\text { Byrsonima } \\
\text { coccolobifolia Kunth } \\
\text { (3) }\end{array}$ & 97 & 1.8 \\
\hline $\begin{array}{l}\text { Caldas Novas- } \\
\text { GO (Santos et al. } \\
\text { 2012) }\end{array}$ & Cerrado & $\begin{array}{c}\text { Leguminosae (14), } \\
\text { Vochysiaceae (8) } \\
\text { Malpighiaceae (5) }\end{array}$ & $\begin{array}{l}\text { Qualea (8) } \\
\text { Andira (6) }\end{array}$ & $\begin{array}{l}\text { Andira paniculata } \\
\text { Benth. (5) } \\
\text { Caryocar brasiliense } \\
\text { Cambess. (3) } \\
\text { Qualea parviflora } \\
\text { Mart. (3) } \\
\text { Qualea grandiflora } \\
\text { Mart. (3) }\end{array}$ & 56 & 1.6 \\
\hline $\begin{array}{c}\text { Serra dos } \\
\text { Pireneus, GO } \\
\text { (Araújo et al. } \\
\text { 2011) }\end{array}$ & $\begin{array}{l}\text { Gallery } \\
\text { forest } \\
\text { Cerrado }\end{array}$ & $\begin{array}{c}\text { Leguminosae (8) } \\
\text { Styracaceae (6) } \\
\text { Malpighiaceae (5) }\end{array}$ & $\begin{array}{c}\text { Styrax L. (6) } \\
\text { Qualea (4) }\end{array}$ & $\begin{array}{c}\text { Styrax pohlii (5) } \\
\text { Andira paniculata (3) } \\
\text { Qualea parviflora (3) } \\
\text { Davilla elliptica A. } \\
\text { St.-Hil. (2) }\end{array}$ & 62 & 1.2 \\
\hline
\end{tabular}


TABLE II (continuation)

\begin{tabular}{|c|c|c|c|c|c|c|}
\hline Locality & Biomes & Richest families & Richest genera & Richest species & $\begin{array}{l}\text { Number of } \\
\text { morphotypes }\end{array}$ & $\begin{array}{c}\text { Mean of } \\
\text { morphotypes }\end{array}$ \\
\hline $\begin{array}{l}\text { Goiânia, GO } \\
\text { (Santos et al. } \\
\text { 2010) }\end{array}$ & Cerrado & $\begin{array}{c}\text { Leguminosae (9) } \\
\text { Styracaceae (6) } \\
\text { Ulmaceae (4) }\end{array}$ & $\begin{array}{c}\text { Styrax (6) } \\
\text { Celtis L. (3) } \\
\text { Inga Mill. (3) } \\
\text { Serjania (3) } \\
\text { Trema Lour. (3) }\end{array}$ & $\begin{array}{c}\text { Styrax pohlii (6) } \\
\text { Inga cylindrica } \\
\text { (Vell.) Mart. (3) } \\
\text { Serjania } \\
\text { obtusidentata Radlk. } \\
\text { (3) } \\
\text { Trema micrantha (L.) } \\
\text { Blume (3) }\end{array}$ & 34 & 1.9 \\
\hline $\begin{array}{l}\text { Serra do Cipó, } \\
\text { MG (Coelho et } \\
\text { al. 2009) }\end{array}$ & Cerrado & $\begin{array}{l}\text { Fabaceae (22) } \\
\text { Myrtaceae (11) } \\
\text { Asteraceae (8) }\end{array}$ & $\begin{array}{c}\text { Bauhinia }(10) \\
\text { Myrcia }(6) \\
\text { Celtis }(6) \\
\text { Serjania }(6)\end{array}$ & $\begin{array}{c}\text { Baccharis } \\
\text { dracunculifolia DC. } \\
\text { (5) } \\
\text { Bauhinia brevipes } \\
\text { Vogel (2) } \\
\text { Celtis brasiliensis } \\
\text { (Gardner) Planch. (1) } \\
\text { Terminalia argentea } \\
\text { Mart. (1) }\end{array}$ & 92 & 1.8 \\
\hline $\begin{array}{c}\text { Santa Rita do } \\
\text { Passa Quatro, SP } \\
\text { (Urso-Guimarães } \\
\text { and Scarelli- } \\
\text { Santos 2006) }\end{array}$ & Cerrado & $\begin{array}{c}\text { Fabaceae (7) } \\
\text { Myrtaceae (5) } \\
\text { Annonaceae (4) }\end{array}$ & $\begin{array}{l}\text { Myrcia (4) } \\
\text { Duguetia A. } \\
\text { St.-Hil. (3) } \\
\text { Bauhinia (3) }\end{array}$ & $\begin{array}{c}\text { Duguetia furfuracea } \\
\text { (A. St.-Hil.) Saff. (3) } \\
\text { Myrcia bella } \\
\text { Cambess. (3) } \\
\text { Bauhinia rufa } \\
\text { (Bong.) Steud. (3) }\end{array}$ & 32 & 1.3 \\
\hline $\begin{array}{c}\text { Tiradentes, } \\
\text { MG (Maia and } \\
\text { Fernandes 2004) }\end{array}$ & Cerrado & $\begin{array}{c}\text { Leguminosae (20) } \\
\text { Myrtaceae (18) } \\
\text { Asteraceae (16) } \\
\text { Melastomataceae } \\
\text { (14) }\end{array}$ & $\begin{array}{c}\text { Croton L. (4) } \\
\text { Vernonia } \\
\text { Schreb. (4) }\end{array}$ & $\begin{array}{c}\text { Protium } \\
\text { heptaphyllum (7) } \\
\text { Copaifera } \\
\text { langsdorffii (6) } \\
\text { Croton floribundus } \\
\text { Spreng. (5) }\end{array}$ & 137 & 1.9 \\
\hline $\begin{array}{c}\text { Delfinópolis, } \\
\text { MG (Urso- } \\
\text { Guimarães et al. } \\
\text { 2003) }\end{array}$ & $\begin{array}{c}\text { Gallery } \\
\text { forest } \\
\text { Cerrado }\end{array}$ & $\begin{array}{l}\text { Leguminosae (2) } \\
\text { Rubiaceae (2) } \\
\text { Vochisyaceae (2) }\end{array}$ & $\begin{array}{c}\text { Bauhinia (2) } \\
\text { Chomelia } \\
\text { Jacq. (2) } \\
\text { Qualea (2) }\end{array}$ & $\begin{array}{l}\text { Bauhinia ungulata } \\
\text { L. (2) } \\
\text { Chomelia pohliana } \\
\text { Müll. Arg. (2) } \\
\text { Qualea parviflora (2) }\end{array}$ & 22 & 1.2 \\
\hline $\begin{array}{c}\text { Três Marias, } \\
\text { MG (Gonçalves- } \\
\text { Alvim and } \\
\text { Fernandes 2001) }\end{array}$ & Cerrado & $\begin{array}{l}\text { Leguminosae (24) } \\
\text { Myrtaceae (10) } \\
\text { Malpighiaceae (8) } \\
\text { Asteraceae (7) }\end{array}$ & $\begin{array}{c}\text { Byrsonima }(6) \\
\text { Myrcia }(5) \\
\text { Copaifera }(4)\end{array}$ & $\begin{array}{c}\text { Byrsonima } \\
\text { coccolobifolia Kunth } \\
\text { (4) } \\
\text { Myrcia } \text { sp. (4) } \\
\text { Bauhinia brevipes (3) } \\
\text { Bowdichia } \\
\text { virgilioides Kunth (3) }\end{array}$ & 92 & 1.5 \\
\hline
\end{tabular}

and six distinct gall morphotypes in Cerrado and Gallery forest sites, respectively.

Galls were previously surveyed in the municipality of Caetité in areas of Cerrado and in Caatinga-Cerrado transition zones in the Serra
Geral Mountains (Costa et al. 2014a, b, Nogueira et al. 2016). The current study, however, represents the first inventory undertaken in an area of Gallery forest in that municipality. The inventory undertaken by Costa (2014b) recorded 35 gall 
morphotypes, distributed among 17 plant families, with Leguminosae and Myrtaceae having the highest number of species hosting galls. Nogueira et al. (2016) reported 49 distinct gall morphotypes on 13 plant species belonging to 12 families. Leguminosae was the principal host plant family (with 22 morphotypes), followed by Malpighiaceae (10). Current survey undertaken in Caetité along the Jacaraci trail showed the greatest richness of gall morphotypes recorded for Bahia State (63), 46 of which occur in Cerrado vegetation and 17 in Gallery forest. These results may reflect, however, a greater sampling effort and winder duration, the fact that collections were made during both the rainy and dry seasons, and the number of collectors (2-3 individuals), and their experience for field work, as suggested by Costa (2016).

The galls recorded had been induced on leaves, stems, buds, and fruits, with leaves being the organs most affected, whether in the Cerrado or Gallery forest; no galls were observed on flowers. These results are similar to other studies undertaken in different vegetation types in Brazil, where galls have been observed predominately on leaves (Julião et al. 2005, Maia et al. 2008, Nogueira et al. 2016, Santos et al. 2010, Araújo et al. 2012), a fact that is probably related to the nutrient reserves present in these organs (Mani 1964).

Most of the galls were isolated and contained only a single larval chamber, a result similar to those of Costa et al. (2014a, b) and GonçalvesAlvim and Fernandes (2001). Only 37\% had some pilosity, with being the other glabrous (63\%). The presence of trichomes on the galls may help defend against natural enemies, reduce water losses, and help maintain mild internal temperatures (Moura et al. 2009).

In terms of their shapes, most galls were globoid, marginal roll or lenticular in both of the environments surveyed. Globoid galls have been the predominant morphotype described in all of the inventories undertaken in the Neotropical region
(Isaias et al. 2013). Similar results were found in Restinga areas in Rio de Janeiro State (Maia 2013), Caatinga-Cerrado sites in Bahia (Costa et al. 2014b) and Gallery forest in Minas Gerais (UrsoGuimarães et al. 2003).

The identification of 48 gall-inducing insects were quite difficult due to the small number of samples (with most galls showing incomplete development of the gall-inducing insects) - and they remained undetermined. The gall-inducing insects that could be identified belonged to the orders Diptera, Lepidoptera, and Thysanoptera; most were Diptera (Cecidomyiidae) (53\% of the total). Cecidomyiidae constitute the largest family of that order, comprising 6,590 species belonging to 812 globally distributed genera (Gagné and Jaschhof 2017). The galls of the Lepidoptera are usually encountered on the stems and buds (Maia 2006), but we recorded their induction on the leaves of Bauhinia pulchella Benth. and Bauhinia sp. and on the buds of Plinia peruviana they were also recorded as associated fauna in cecidomyiid galls on Qualea parviflora Mart.

We recorded two gall morphotypes induced by Thysanoptera in an unidentified species of Malpighiaceae and on Eugenia sp. (Myrtaceae), both on their leaves. These results confirm the plant preferences of those organisms for inducing leaf galls (Maia 2006).

In addition to the gall-inducing insects, there is also a distinct insect fauna associated with the galls themselves. Those arthropods vary in terms of their feeding habits and can be classified as: parasitoids, predators, inquilines, and successors (Maia 2001). The microfauna associated with the galls in the present study was composed of Hymenoptera, Hemiptera, Lepidoptera, Thysanoptera, Coleoptera, Collembola, Araneae, and Pseudoscorpionida. The order Hymenoptera had the greatest number of records, occurring on galls observed on Asteraceae Indet., Moquiniastrum sp., Combretum leprosum Mart., Caliandra macrocalyx Harms, Myrtaceae 
Indet., Solanaceae Indet., and Turneraceae Indet. This order stands out for its parasitoids, as reported in various studies, being considered the principal taxon responsible for the deaths of gall-inducing insects. Species of Hymenoptera have been reported as parasitoids in areas of Cerrado (Maia and Fernandes 2004, Maia et al. 2008) and Gallery forest (Costa 2016), corroborating the current results.

Inquilines are organisms that simultaneously inhabit the galls and feed on the plant tissues within it - thus competing with the gall-inducing insects (Naredran et al. 2007). The inquilines encountered in the present study belonged to the Hemiptera, Lepidoptera, Thysanoptera, and Coleoptera. These same orders have also been recorded in Cerrado (Maia and Fernandes 2004) and Gallery forest sites (Costa 2016).

The fauna of successors was composed of ants, spiders, pseudoscorpions, arachnids, and Collembola - representing organisms that occupy the galls after they have been abandoned by the inducing-species. While pseudoscorpions have only infrequently been reported in galls (Maia 2001, 2011, Carvalho-Fernandes et al. 2012, Maia and Souza 2013, Costa et al. 2014a, Nogueira et al. 2016), we identified them in abandoned galls on Psidium brownianum Mart. ex DC. (Myrtaceae); other studies have recorded these organisms on two species of Myrtaceae [Myrcia tomentosa (Aubl.) DC. (Maia 2001) and Eugenia astringens Cambess.] (Costa 2014b).

Even though the study area was not extensive (a trail approximately $3 \mathrm{Km}$ long), a considerable diversity of galls was observed. Of the 47 host plant taxa identified, eight were identified for the first time as gall hosts for Brazil. These results reinforce the importance of undertaking inventories of galls and their host plants in unsampled areas throughout that country, since it will contribute to the knowledge about plant species, galling insects and their interactions among different environments.

\section{ACKNOWLEDGMENTS}

The authors thank Dr. Flávio França (UEFS), Dr. Efigênia de Melo (UEFS), and Dr. Marcos Sobral (UFSJ) for the identifications of the botanical material. This study composes part of the course conclusion monograph of the first author, which was supported by the Departamento de Ciências Humanas da Universidade do Estado da Bahia, Campus VI, the Programa de Pós-Graduação em Biodiversidade Vegetal (PPGBveg/UNEB), the Conselho Nacional de Desenvolvimento Científico e Tecnológico (CNPq) (Proc. no 406111/2016-2), and the Fundação de Amparo à Pesquisa do Estado da Bahia (FAPESB) (Proc. no 9648/2015).

\section{REFERENCES}

ALMADA ED AND FERNANDES GWA. 2011. Insetos indutores de galhas em florestas de terra firme e em reflorestamentos com espécies nativas na Amazônia Oriental, Pará, Brasil. Bol Mus Para Emílio Goeldi Cienc Nat 6: 163-196.

APG IV - ANGIOSPERM PHYLOGENY GROUP. 2016. An update of the Angiosperm Phylogeny Group classification for the orders and families of flowering plants: APG IV. Bot J Linn Soc 181: 1-20.

ARAÚJO WS, JÚNIOR EDP, RIBEIRO BA, SILVA TM, SILVA EC, GUILHERME FAG, SCARELI-SANTOS C AND SANTOS BB. 2015. Checklist of host plants of insect galls in the state of Goiás in the Midwest Region of Brazil. Biodivers Data J 3: 1-21.

ARAÚJO WS, PORFÍRIO-JUNIOR ED, JORGE VA AND FILHO KES. 2012. Plantas hospedeiras e galhas entomógenas em sub-bosques de florestas tropicais do Pará, Brasil. Insula 41: 59-72.

ARAÚJO WS, SANTOS BB AND GOMES-KLEIN VL. 2011. Insect galls from Serra dos Pireneus, GO, Brazil. Biota Neotrop 11: 357-364.

ARAÚJO WS, SOBRAL FL AND MARACAHIPES L. 2014. Insect galls of the Parque Nacional das Emas (Mineiros, GO, Brazil). Check List 10: 1445-1451.

ARDUIN M AND KRAUS JE. 2001. Anatomia de galhas de ambrosia em folhas de Baccharis concinna e Baccharis dracunculifolia (Asteraceae). Rev Bras Bot 24: 63-72.

ASTERACEAE IN LISTA DE ESPÉCIES DA FLORA DO BRASIL 2020 EM CONSTRUÇÃO. Jardim Botânico do Rio de Janeiro. Disponível em http://floradobrasil.jbrj.gov. br/reflora/floradobrasil/FB55. Acesso em 14 de Maio de 2017. 
BEGON M, TOWNSEND CR AND HARPER JL. 2007. Ecologia de indivíduos a ecossistemas. $4^{\mathrm{a}}$ ed., Artmed: Porto Alegre, $752 \mathrm{p}$.

BERGAMINI BAR, BERGAMIN LL, SANTOS BB AND ARAÚJO WS. 2017. Occurrence and characterization of insect galls in the Floresta Nacional de Silvânia, Brazil. Pap Avulsos Zool 57: 413-431.

CARNEIRO MAA, BORGES RAX, ARAÚJO APA AND FERNANDES GW. 2009. Insetos indutores de galhas da porção sul da Cadeia do Espinhaço, Minas Gerais, Brasil. Rev Bras Ent 53: 570-592.

CARVALHO-FERNANDES SP, ALMEIDA-CORTEZ JS AND FERREIRA ALN. 2012. Riqueza de galhas entomógenas em áreas antropizadas e preservadas de caatinga. Rev Árvore 36: 269-277.

COELHO MS, ALMADA ED, FERNANDES GW, CARNEIRO MAA, SANTOS RM, QUINTINO AV AND SANCHEZ-AZOFEIFA A. 2009. Gall inducing arthropods from a seasonally dry tropical forest in Serra do Cipó, Brazil. Rev Bras Ent 53: 404-414.

COELHO MS, CARNEIRO MAA, BRANCO CA AND FERNANDES GW. 2013. Gall-inducing insectsfrom Serra do Cabral, Minas Gerais, Brazil. Biota Neotrop 13: 102-109.

COSTA EC. 2016. Galhas do Parque Estadual da Serra dos Montes Altos e Refúgio de Vida Silvestre: diversidade e desenvolvimento. Paulo Afonso: Universidade do Estado da Bahia,179 p. (Unpublished).

COSTA EC, CARVALHO-FERNANDES SP AND SANTOSSILVA J. 2014a. Galhas de insetos em uma área de transição caatinga-cerrado no Nordeste do Brasil. Sitientibus Ser Ci Biol 14: 1-9.

COSTA EC, CARVALHO-FERNANDES SP AND SANTOSSILVA J. 2014b. Galhas entomógenas associadas à Leguminosae do entorno do riacho Jatobá, Caetité, Bahia, Brasil. R Bras Bioci 12: 115-120.

FERNANDES GW, CARNEIRO MAA, LARA ACF, ALLAIN LA, ANDRADE GI, JULIÃO G, REIS TC AND SILVA IM. 1996. Galling insects on neotropical species of Baccharis (Asteraceae). Trop Zoo 9: 315-332.

FERNANDES SPC, CASTELO-BRANCO BP, ALBUQUERQUE FA, FERREIRA ALN, BRITORAMOS AB, BRAGA DVV AND ALMEIDA-CORTEZ J. 2009. Galhas entomógenas em um fragmento urbano de Mata Atlântica no Centro de Endemismo de Pernambuco. R Bras Bioci 7: 240-244.

GAGNÉ RJ AND JASCHHOF M. 2017. A catalog of the Cecidomyiidae (Diptera) of the World. Fourth Edition, Digital, $762 \mathrm{p}$.

GONÇALVES-ALVIM SJ AND FERNANDES GW. 2001. Comunidades de insetos galhadores (Insecta) em diferentes fisionomias do cerrado em Minas Gerais, Brasil. Rev Bras Zool 18: 289-305.

HORI K. 1992. Insect secretions and their effect on plant growth, with special reference to hemipterans. In: Shorthouse JD and Rohfritsch O (Eds), Biology of insect-induced galls. Oxford, Oxford University Press, p. 157-170.

ISAIAS RMS, CARNEIRO RGS, OLIVEIRA DC AND SANTOS JC. 2013. Illustrated and Annotated Checklist of Brazilian Gall Morphotypes. Neotrop Entomol 42: 230-239.

ISAIAS RMS, OLIVEIRA DC AND CARNEIRO RGS. 2011. Role of Euphalerus ostreoides (Hemiptera: Psylloidea) in manipulating leaflet ontogenesis of Lonchocarpus muehlbergianus (Fabaceae). Botany 89: 581-592.

JULIÃO GR, FERNANDES GW, NEGREIROS D, BEDÊ L AND ARAÚJO RA. 2005. Insetos galhadores associados a duas espécies de plantas invasoras de áreas urbanas e periurbanas. Rev Bras Ent 49: 97-106.

JULIÃO GR, VENTICINQUE EM, FERNANDES GW AND PRICE PW. 2014. Unexpected High Diversity of Galling Insects in the Amazonian Upper Canopy: The Savanna Out There. PLoS ONE 9: 1-20.

LPWG - LEGUME PHYLOGENY WORKING GROUP. 2017. A new subfamily classification of the Leguminosae based on a taxonomically comprehensive phylogeny. Taxon: 66(1): 44-77.

LUZ GR, FERNANDES GW, SILVA JO, NEVES FS AND FAGUNDES M. 2012. Galhas de insetos em habitats xérico e mésico em região de transição Cerrado Caatinga no norte de Minas Gerais, Brasil. Neotrop Biol Conserv 7: $171-187$.

MAIA VC. 2001. The gall midges (Diptera, Cecidomyiidae) from three restingas of Rio de Janeiro State, Brazil. Rev Bras Zool 18: 583-629.

MAIA VC. 2006. Galls of Hemiptera, Lepidoptera and Thysanoptera from Central and South America. Publ Avul Mus Nac 110: 3-22.

MAIA VC. 2011. Characterization of insect galls, gall makers, and associated fauna of Platô Bacaba (Porto de Trombetas, Pará, Brazil). Biota Neotrop 4: 37-53.

MAIA VC. 2013. Galhas de insetos em restingas da região sudeste do Brasil com novos registros. Biota Neotrop 13: 183-209.

MAIA VC. 2014. New state record of four species of gall midges (Insecta, Diptera, Cecidomyiidae). Check List 10: 942-943.

MAIA VC AND FERNANDES GW. 2004. Insect galls from Serra de São José (Tiradentes, MG, Brazil). Braz J Biol 64: 423-445.

MAIA VC, FERNANDES GW, MAGALHÃES H AND SANTOS JC. 2010. Two new species of Lopesia Rübsaamen (Diptera, Cecidomyiidae) associated with Mimosa hostilis (Mimosaceae) in Brazil. Rev Bras Ent 54: 578-583.

MAIA VC, MAGENTA MAG AND MARTINS SE. 2008. Ocorrência e caracterização de galhas de insetos em áreas de restinga de Bertioga (São Paulo, Brazil). Biota Neotrop 8: 167-197. 
MAIA VC AND OLIVEIRA JC. 2010. Insect galls of the Reserva Biológica Estadual da Praia do Sul (Ilha Grande, Angra dos Reis, RJ). Biota Neotrop 10: 227-238.

MAIA VC AND SOUSA LI. 2007. Estudos taxonômicos e morfológicos de uma nova espécie de Cecidomyiidae (Diptera) indutora de galhas em Tetrapteres Phlomoides (Malpighiaceae). Saúde \& Amb Rev 1: 77-85.

MAIA VC AND SOUZA MC. 2013. Insect galls of the xeric vegetation of Ilha do Cabo Frio (Arraial do Cabo, RJ, Brazil). Biota Neotrop 13: 278-288.

MANI MS. 1964. Ecology of Plant Galls. W. Junk, The Hague, $434 \mathrm{p}$.

MENDONÇA MS. 2007. Plant diversity and galling arthropod diversity-searching for taxonomic patterns in an animalplant interaction in the Neotropics. Bol Soc Argent Bot 42: 347-357.

MENDONÇA RC, FELFILI JM, WALTER BMT, SILVA JR MC, REZENDE AV, FILGUEIRAS TS, NOGUEIRA PE AND FAGG CW. 2008. Flora Vascular do bioma Cerrado: checklist com 12.356 espécies. In: Sano SM, Almeida SP and Ribeiro JF (Eds), Cerrado: ecologia e flora. Embrapa Cerrados, Planaltina, p. 421-1279.

MINISTÉRIO DO MEIO AMBIENTE. 2002. Biodiversidade Brasileira: Avaliação e identificação de áreas e ações prioritárias para a conservação, utilização sustentável e repartição dos benefícios da biodiversidade nos biomas brasileiros. Brasília: MMA/SBF, p. 404.

MOREIRA RG, FERNANDES GW, ALMADA ED AND SANTOS JC. 2007. Galling insects as bioindicators of land restoration in an area of Brazilian Atlantic Forest. Lundiana 8: 107-112.

MOURA MZD, SOARES GLG AND ISAIAS RMS. 2009. Ontogênese da folha e das galhas induzidas por Aceria lantanae Cook (Acarina: Eriophyidae) em Lantana camara L. (Verbenaceae). Rev Bras Bot 32: 271-282.

NARENDRAN TC, SANTHOSH S AND SUDHEER K. 2007. Biosysyematics and biogeography of oriental Chalcidoidea (Hymenoptera) associated with plant galls. Orient insects 41: 141-167.

NOGUEIRA RM, COSTA EC, CARVALHO-FERNANDES SP AND SANTOS-SILVA, J. 2016. Insect galls from Serra Geral, Caetité, Bahia, Brazil. Biota Neotrop 16: e20150035.

OLIVEIRA DC AND ISAIAS RMS. 2010. Redifferentiation of leaflet tissues during midrib gall development in Copaifera langsdorffii (Fabaceae). S Afr J Bot 76: 239-248.

OLIVEIRA JC. 2009. Viabilidade de espécies galhadoras (Diptera, Cecidomyiidae) e parasitóides (Hymenoptera) associadas à Guapira opposita (Vell.) (Nyctaginaceae) como bioindicadores da qualidade ambiental. Dissertação de Doutorado, Universidade Federal do Rio de Janeiro, Rio de Janeiro.

PRICE PW. 1991. The plant vigor hypothesis and herbivore attack. Oikos 62: 244-251.

SANTOS BB, FERREIRA HD AND ARAÚJO WS. 2010. Ocorrência e caracterização de galhas entomógenas em uma área de floresta estacional semidecídua em Goiânia, Goiás, Brasil. Acta Bot Bras 24: 243-249.

SANTOS BB, RIBEIRO BA, SILVA TM AND ARAÚJO WS. 2012. Galhas de insetos em uma área de cerrado sentido restrito na região semi-urbana de Caldas Novas (Goiás, Brasil). R Bras Bioci 10: 439-445.

SANTOS JC, ALMEIDA-CORTEZ JS AND FERNANDES GW. 2011. Richness of gall-inducing insects in the tropical dry forest (Caatinga) of Pernambuco. Rev Bras Ent 55: 45-54.

SCHOONHOVEN LM, VAN LOON JJA AND DICKE M. 2005. Insect-Plant Biology, $2^{\text {nd }}$ ed., Oxford University Press: Oxford.

SILVA PSD, KNOECHELMANN CM, TABARELLI M AND ALMEIDA-CORTEZ JS. 2011. Richness of gall morphospecies along a secondary successional gradient of Atlantic Forest in northeastern Brazil. R Bras Bioci 9: 270-277.

STONE GN AND SCHÖNROGGE K. 2003. The adaptive significance of insect gall morphology. Trends Ecol Evol 18: 512-522.

SUZUKI AY, BEDETTI CS AND ISAIAS RMS. 2015. Detection and distribution of cell growth regulators and of cellulose microfibrils during the development of Lopesia sp. galls on Lonchocarpus cultratus (Fabaceae). Botany 93: 435-444.

TABARELLI M. 1998. Dois Irmãos: o desafio da conservação biológica em um fragmento de Floresta Tropical. In: Machado IC, Lopez AV and Porto KC (Orgs), Reserva Ecológica de Dois Irmãos: estudos em um remanescente de Mata Atlântica em área urbana (Recife-PernambucoBrasil). Ed. Universitária, Universidade Federal de Pernambuco, p. 311-323.

URSO-GUIMARÃES MV AND SCARELI-SANTOS C. 2006. Galls and gallmakers in plants from Pé-de-Gigante Cerrado Reserve, Santa Rita do Passa Quatro, SP, Brazil. Braz J Biol 66: 357-369.

URSO-GUIMARÃES MV, SCARELI-SANTOS C AND BONIFÁCIO-SILVA AC. 2003. Occurrence and characterization of entomogen galls in plants from natural vegetation areas in Delfinópolis, MG, Brazil. Braz J Biol 63: 705-715. 